\title{
Retraction of Effects of the Combination of Synchronous Web- Based Teaching with Visually Creative Teaching on Art Students' Creativity
}

Li Ruan *

Issue Date: 15 January 2019

Original Article: Effects of the Combination of Synchronous Web-Based Teaching with Visually Creative Teaching on Art Students' Creativity

EURASIA J. Math., Sci Tech. Ed (2018), 14(7), 3245-3251.

https:// doi.org/10.29333/ejmste/90627

This document states that the Article is retracted by request from the author.

\section{http://www.ejmste.com}

